\title{
同 \\ A Successfully Treated Severe Case of Extensively Drug-Resistant Tuberculosis During Pregnancy
}

\author{
Gebelik Döneminde Başarı ile Tedavi Edilen Ağır Yaygın İlaç Dirençli \\ Tüberküloz Olgusu
}

Mehmet Ünlü, Pınar Çimen, Gülsüm Arı, Mustafa Şevket Dereli

\section{Abstract}

$n$
0
0
0
0
$u$
4
0
0
0
$\frac{1}{0}$
$\frac{1}{4}$
0

The widespread emergence of extensively drugresistant tuberculosis is an increasing global health care problem and affects young adults, including women of childbearing age. The treatment of extensively drug-resistant tuberculosis during pregnancy is still controversial and therapeutic abortions were previously recommended for pregnant patients. We describe herein a severe case of extensively drugresistant tuberculosis that was successfully treated during pregnancy. The patient delivered a healthy baby and had no signs of relapse eight months after completing the treatment. In conclusion, extensively drug-resistant tuberculosis can be treated successfully during gestation and pregnant women should have the option to continue their pregnancy.

Key words: Extensively drug-resistant tuberculosis, treatment, pregnancy, directly observed therapy.

\section{Özet}

Yaygın ilaç dirençli tüberküloz artış gösteren bir global sağlık problemidir ve doğurganlık çağındaki kadınları da içeren genç erişkinleri etkilemektedir. Gebelik döneminde gelişen yaygın ilaç dirençli tüberküloz olgularının tedavisi hala tartışmalı olup geçmişte gebe hastalara terapötik abortus uygulaması önerilmiştir. Bu yazıda gebelik sonlandırılmadan başarı ile tedavi edilen yaygın ilaç dirençli bir tüberküloz olgusu sunulmuştur. Hasta sağlıklı bir bebek doğurmuş olup, tedavinin bitiminden 8 ay sonra relapsı işaret eden herhangi bir bulgusu da yoktur. Sonuç olarak, yaygın ilaç dirençli tüberküloz gebelikle birlikte başarı ile tedavi edilebilir bir hastalıktır ve bu durumdaki kadınların gebeliklerini devam ettirme şansı kendilerine tanınmalıdır.

Anahtar Sözcükler: Yaygın ilaç dirençli tüberküloz, tedavi, gebelik, doğrudan gözetim altında tedavi.

Clinic of Chest Diseases, Dr. Suat Seren Chest Diseases and

Surgery Training and Research Hospital, ìmir, Turkey

Dr. Suat Seren Göğüs Hastalıkları ve Cerrahisi Eğitim ve Araștırma Hastanesi, Göğüs Hastalıkları Kliniği, İzmir

Submitted (Başvuru tarihi): 08.07.2014 Accepted (Kabul tarihi): 25.08.2014

Correspondence (iletişim): Mehmet Ünlü, Clinic of Chest Diseases, Dr. Suat Seren Chest Diseases and Surgery Training and Research Hospital, İzmir, Turkey

e-mail: lidokain21@hotmail.com 
The advent of antibiotics and the adoption of directly observed therapy (DOT) for the treatment of tuberculosis (TB) represented a major breakthrough in the fight against the disease. However, TB still remains a leading cause of morbidity and mortality all over the world, and drug-resistant strains of TB are rapidly emerging worldwide (1). The treatment of extensively drug-resistant tuberculosis (XDR-TB) relies on drugs that are less potent and more toxic than those used to treat drug-susceptible strains. Thus, treatment success is lower and mortality is higher than achieved in nonresistant TB (2). On the other hand, XDR-TB is a global public health problem affecting women of childbearing age, and little is known about the safety of the drugs used to treat XDR-TB during pregnancy. It is possible to treat such cases during pregnancy with the right combination of the antimycobacterial drugs and close medical follow-up.

Here we report a severe case of pregnant XDR-TB that was treated successfully without termination of pregnancy.

\section{CASE}

A 25-year-old Azerbaijani female presented to the emergency department of our hospital with dyspnea, chronic cough, night sweats, and intermittent high fever. She had a history of pulmonary TB, which was diagnosed and treated in Azerbaijan with six months of self-administered therapy in 2007. Although she mentioned that her disease was treated successfully, the result of this treatment procedure was not clear. She was illiterate and had no written information about her past medical history. She had fewer symptoms after the six-month treatment regimen, and migrated to the Russian Federation to find employment. Her health status worsened again five months after migration, and she received TB relapse treatment in the Russian Federation in the form of oral drugs and injectable agents for three months before defaulting treatment due to economical problems. The content of this treatment regimen was unclear. She did not receive antimycobacterial treatment for three years and moved to Turkey in January 2011 to seek medical treatment.

She was hospitalized under air-borne isolation in a negative pressure room in the TB department of our hospital. The examination of blood samples revealed leukocytosis $\left(29,400 / \mathrm{mm}^{3}\right)$, anemia (hemoglobin: $10.4 \mathrm{~g} / \mathrm{dl}$ ) and thrombocytosis $\left(607,000 / \mathrm{mm}^{3}\right)$. The results of the blood chemistry tests were within normal limits. Erythrocyte sedimentation rate was $110 \mathrm{~mm} / \mathrm{h}$ and serum level of Creactive protein was $14.5 \mathrm{mg} / \mathrm{dL}$. Tuberculin skin test
(TCT) was measured as 18 millimeters at the end of 72 hours and anti-HIV antibody tests were negative. There was no history of chronic diseases and she was a life-long non-smoker. The measurement of arterial blood gas analysis revealed the following values: $\mathrm{pH}: 7.44, \mathrm{PaCO}_{2}$ : $32 \mathrm{~mm} \mathrm{Hg}, \mathrm{PaO}_{2}: 49 \mathrm{~mm} \mathrm{Hg}, \mathrm{HCO}_{3}: 27 \mathrm{mmol} / \mathrm{L}$ and $\mathrm{SaO}_{2}: 86 \%$, this was compatible with hypoxemic respiratory failure. Her chest radiograph findings included reticulonodular opacities throughout both lungs, and cavity formations located in the upper zones of the lungs (Figure 1). Computerized tomography of the thorax (thorax-CT) demonstrated a loss of lung volume, cystic and varicose enlargements of the bronchial tree, cavity formations, and consolidations in the different zones of both lungs (Figure 2). Upon presentation to our hospital, her sputum acidfast bacillus (AFB) smear was $3+$. Rapid polymerase chain reaction (PCR)-based antimicrobial susceptibility testing detected Mycobacterium tuberculosis with mutations in the katG and rpoB genes, indicating resistance to isoniazid and rifampicin, respectively. Her history indicated a case of multidrug-resistant tuberculosis (MDR-TB), and therefore, a combination treatment involving secondline drugs (moxifloxacin, ethionamide, cycloserine, paraaminosalicylic acid, capreomycin, and clofazimine) was initiated while awaiting the results of the drug susceptibility testing (DST). The BACTEC MGIT 960 System showed Mycobacterium tuberculosis complex (MTC) resistance to all oral first-line drugs (isoniazid, rifampicin, pyrazinamide, ethambutol, and streptomycin). Furthermore, the Epsilometer test (Etest) determined mutations in the gyrA and rrs genes, which were compatible with the resistance to oral fluoroquinolones and injectable second line agents. As a result, the patient was diagnosed with XDR-TB. The treatment regimen continued with the same drugs, and clarithromycin with amoxicillin-clavulanic acid were added to her remaining therapy.

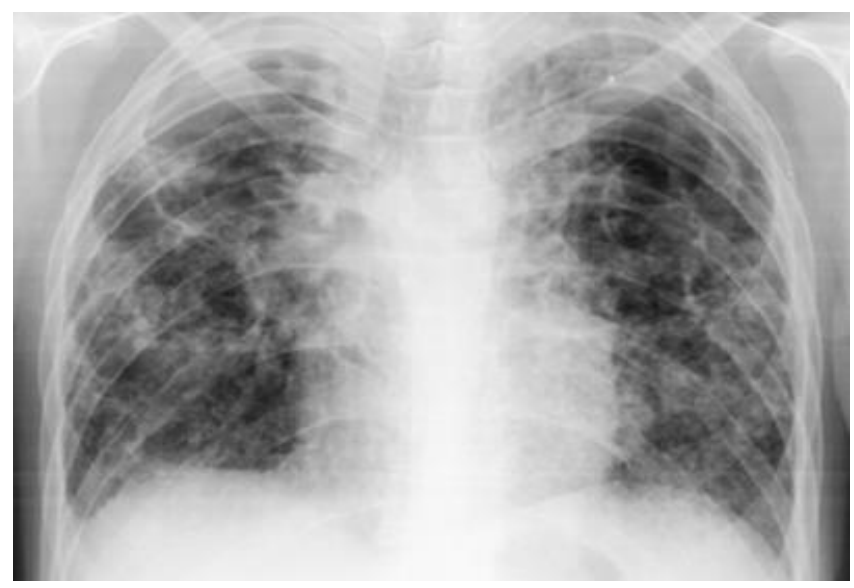

Figure 1: Chest radiograph of the patient on admission 


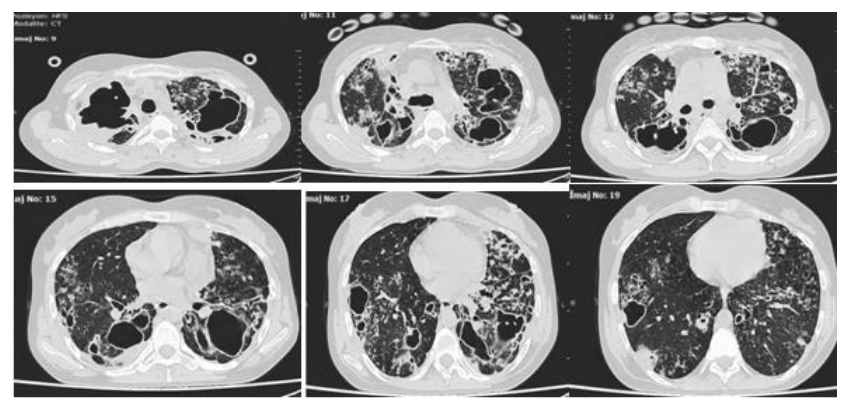

Figure 2: Images of the computerized tomography of the thorax on admission

The treatment regimen was administered under inpatient directly observed therapy (DOT) and her clinical condition was complicated by drug-related side effects and toxicity after some time. At the second month of the treatment, she expressed the signs of depression and suicidal tendencies, which were attributed to cycloserine and this drug was discontinued. Hypothyroidism developed, likely as a side effect of ethionamide, which was treated with Lthyroxin replacement. Her shortness of breath decreased and there was no further requirement for oxygen supply.

At the third month of the treatment, she expressed abdominal pain, and the ultrasound examination revealed a 16-week live intrauterine pregnancy. She was referred to the local medical council and recommended her two options after explanation of all possible risks of antimycobacterial drugs: terminate the pregnancy or continue treatment while pregnant. The patient was anxious not to abort and elected to continue her pregnancy. She signed a written consent form in which she mentioned her insist to continue XDR-TB treatment with the pregnancy. Close obstetric follow-up led to a favorable outcome and she delivered a baby who appeared entirely normal at birth. The chest radiograph of the baby included normal findings and TCT was negative at birth. The baby received isoniazid chemoprophylaxis $(10 \mathrm{mg} / \mathrm{kg} /$ day $)$ for three months and at three months of the chemoprophylaxis had no sign of active TB. Therefore, secondary chemoprophylaxis was continued for six months. The baby continues to be monitored after 31 months and no developmental or physical defects have been observed in this baby.

On the other hand, her sputum smears remained AFB positive for months and sputum conversion was achieved after eight months of the continuous in hospital treatment (September 2011). Furthermore, sputum cultures did not demonstrate the growth of MTC after October 2011. There was no change in the treatment regimen in the postpartum period.

We administered the antimycobacterial treatment for two years after the conversion of the sputum culture. She was discharged in September 2013. At the end of the treatment, most of the symptoms disappeared and the chest radiograph (Figure 3) and CT findings improved (Figure 4). Eight months after the completing the treatment, the patient is still under control without signs of relapse.

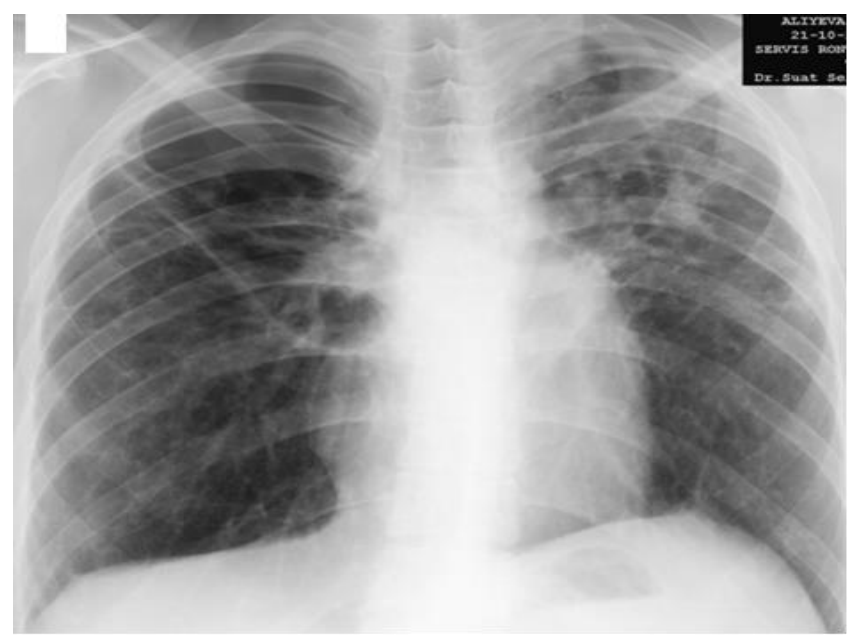

Figure 3: Chest radiograph of the patient at the end of the treatment

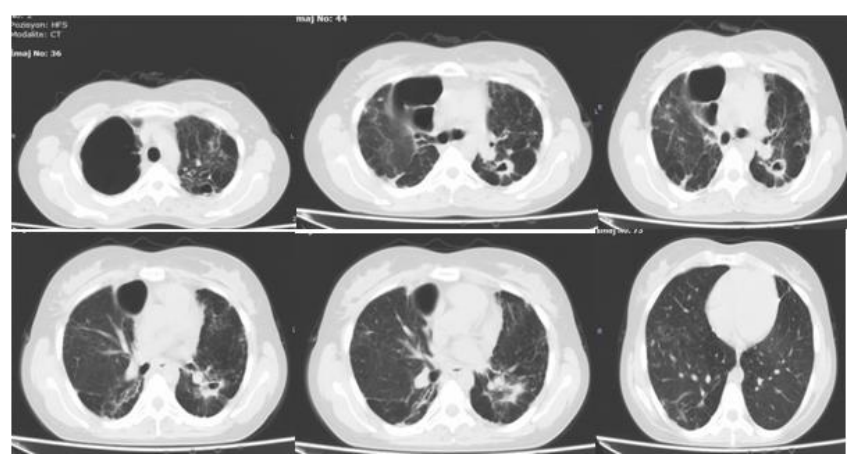

Figure 4: Images of the computerized tomography of the thorax at the end of the treatment

\section{DISCUSSION}

Tuberculosis has affected mankind for thousands of years and the key to successful elimination of TB is the treatment of the cases with optimum chemotherapy (3). With the discovery of chemotherapy and the adoption of the standardized short course treatment, a declining trend of TB was observed in most countries. On the other hand, the spread of MDR-TB has represented a major threat to TB control since the 1990s. In 2006, the World Health Organization (WHO) reported an alarming rise of the drug-resistant TB globally, and described the first cases of XDR-TB $(4,5)$. MDR-TB is defined as resistance to isoniazid and rifampicin, with or without resistance to other firstline drugs, while XDR-TB involves resistance not only to the two best first-line anti-TB medications, rifampicin and isoniazid, but also to at least one of the three injectable 
second-line agents (amikacin, kanamycin, or capreomycin) and to any fluoroquinolone.

WHO Global Tuberculosis Report in 2013 revealed that 8.6 million people became ill with TB and 1.3 million people died from TB in 2012 (6). According to the same report, globally in 2012, an estimated 450,000 people developed MDR-TB, and there were an estimated 170,000 deaths from MDR-TB (6). At least one case of XDR-TB has been reported by 92 countries by the end of 2012 and on average, an estimated $9.6 \%$ of MDR-TB cases had XDR-TB. China, India, and the Russian Federation have the highest burden of resistant-TB followed by 24 other countries. Although Turkey is not among these countries, there is still no national or usable guideline to detect drug-resistance rates in Turkey $(7,8)$.

Several factors are related for the development of drugresistant TB cases. These include non-adherence to the therapy, lack of direct observed treatment, limited or interrupted drug supplies, poor quality of drugs, widespread availability of anti-TB drugs without prescription, poor medical management, and poorly-managed national control programs (9-11). It is likely that all of these factors played a role in the development of XDR-TB in this case.

Although XDR-TB is generally thought to have high mortality rates, it is possible to treat many cases with the proper combination and the rational use of available antimycobacterial drugs. The management of XDR-TB requires at least four drugs to which the MTC isolate is sensitive or likely to be sensitive (12).

Experience with second-line drugs during pregnancy is poorly described and primarily case reports provide guidance for management of XDR-TB in pregnancy (13-15). Therefore, there is a still lack of evidence regarding the safety of second-line drugs. Although all second-line drugs are applicable during pregnancy, they should be used with caution and only when the benefits are thought to outweigh potential risks to the fetus. Treatment regimens should be individualized and patients should be screened for the potential risks of the second-line drugs. If the pregnancy is identified during the first trimester, treatment should be delayed until the second trimester, except in cases of advanced clinical disease. Most second-line agents are FDA pregnancy class $C$, except for aminoglycosides, which are mainly class D. Streptomycin, amikacin, and kanamycin are class $D$, whereas only capreomycin is class $C$. All fluoroquinolones, ethionamide, prothionamide, para-aminosalicylic acid, cycloserine, clofazimine, and clarithromycin are considered as class $\mathrm{C}$.
Only amoxicillin-clavulanic acid is class B and the category of thiacetazone is not determined yet. Shin et al. (16) mentioned that parenteral therapy should be avoided during the first 20 weeks of pregnancy if possible and suggested the consideration of capreomycin among aminoglycosides if parenteral therapy is needed. They also recommended pyridoxine to all pregnant patients receiving ethionamide, prothionamide, or cycloserine. Our treatment regimen included a combination of moxifloxacin $(400 \mathrm{mg} /$ day), ethionamide $(750 \mathrm{mg} /$ day $)$, and cycloserine $(500 \mathrm{mg} /$ day $)$ until the development of psychological symptoms, and para-aminosalicylic acid (8 gr/day), capreomycin $(750 \mathrm{mg} /$ day), clofazimine $(200 \mathrm{mg} /$ day $)$, clarithromycin (1000 mg/day), and amoxicillin-clavulanic acid (4000-250 mg/day).

The optimum duration of the treatment has not yet been determined. However, it is recommended to continue the treatment for a minimum of 18 months after culture conversion, and extend the therapy to 24 months in chronic cases with extensive pulmonary damage (17). The administration of therapy for at least two years is required in most of the patients. We prolonged the antimycobacterial treatment and administered the therapy for two years after the conversion of sputum culture due to severely damaged lung parenchyma of the patient.

Another matter in question related to this topic is how to manage the treatment during pregnancy. Some clinicians recommend termination of the pregnancy (18), whereas others recommend reducing or delaying the treatment during pregnancy $(13,19)$. Consistent with our results, Shin et al. (16) and Palacios et al. (20) reported that successful treatment of drug-resistant TB during gestation is possible.

There are no publications in the literature demonstrating the results of thoracic surgery performed during pregnancy for the treatment of drug-resistant TB.

In conclusion, XDR-TB can be successfully treated during pregnancy and women who become pregnant while being treated for XDR-TB should have the option not to terminate their pregnancy if they accept the possible risks of second-line antimycobacterial drugs. Treatment regimens should be individualized and all patients should be under close medical follow-up for the side effects of the second-line drugs.

\section{CONFLICTS OF INTEREST}

None declared. 


\section{AUTHOR CONTRIBUTIONS}

Concept - M.Ü., P.Ç., G.A., M.S..D.; Planning and Design - M.Ü., P.Ç., G.A., M.Ş.D.; Supervision - M.Ü., P.Ç., G.A., M.Ş.D.; Funding - M.S.D., G.A., P.Ç., M.Ü.; Materials - M.S.D., G.A., P.Ç., M.Ü.; Data Collection and/or Processing - M.S..D., G.A., P.Ç., M.Ü.; Analysis and/or Interpretation - M.S.D., G.A., P.Ç., M.Ü.; Literature Review - M.S..D., G.A., P.Ç., M.Ü.; Writing -; Critical Review - M.S..D., G.A., P.Ç., M.Ü.

\section{YAZAR KATKILARI}

Fikir - M.Ü., P.Ç., G.A., M.Ş.D.; Tasarım ve Dizayn M.Ü., P.Ç., G.A., M.Ş.D.; Denetleme - M.Ü., P.Ç., G.A., M.Ş.D.; Kaynaklar - M.Ş.D., G.A., P.Ç., M.Ü.; Malzemeler - M.Ş.D., G.A., P.Ç., M.Ü.; Veri Toplama ve/veya İşleme - M.S..D., G.A., P.Ç., M.Ü.; Analiz ve/veya Yorum - M.S.D., G.A., P.Ç., M.Ü.; Literatür Taraması - M.S.D., G.A., P.Ç., M.Ü.; Yazıyı Yazan - M.Ş.D., G.A., P.Ç., M.Ü.; Eleştirel İnceleme - M.Ş.D., G.A., P.Ç., M.Ü.

\section{REFERENCES}

1. Shah NS, Wright A, Bai GH, Barrera L, Boulahbal F, Martin-Casabona $\mathrm{N}$, et al. Worldwide emergence of extensively drug-resistant tuberculosis. Emerg Infect Dis 2007; 13:380-7. [CrossRef]

2. Jacobson KR, Tierney DB, Jeon CY, Mitnick CD, Murray MB. Treatment outcomes among patients with extensively drug-resistant tuberculosis: systematic review and metaanalysis. Clin Infect Dis 2010; 51:6-14. [CrossRef]

3. Joshi JM. Tuberculosis chemotherapy in the 21 st century: Back to the basics. Lung India 2011; 28:193-200. [CrossRef]

4. Centers for Disease Control and Prevention. Emergence of Mycobacterium tuberculosis with extensive resistance to second-line drugs-worldwide, 2000-2004. MMWR Morb Mortal Wkly Rep 2006; 55:301-5.

5. Centers for Disease Control and Prevention. Notice to readers: revised definition of extensively drug-resistant tuberculosis. MMWR Morb Mortal Wkly Rep 2006; 55: 1176 .

6. World Health Organization (WHO) Global tuberculosis report 2013. Access date: 23 October 2013. Place of access

7. Türkiye'de Verem Savaşı 2011 Raporu. Access date: 6 November 2012. Place of access
8. Perincek G, Tabakoğlu E, Otkun M, Özdemir L, Özdemir B. Mycobacterium tuberculosis üremesi saptanan akciğer tüberkülozlu hastaların antitüberküloz ilaçlara direnç oranları. Tur Toraks Der 2011; 12:111-3.

9. Farmer P, Bayona J, Becerra M. Multidrug resistant tuberculosis and the need for biosocial perspectives. Int J Tuberc Lung Dis 2001 ; 5:885-6.

10. Zaman K, Rahim Z, Yunus M, Arifeen S, Baqui A, Sack D, et al. Drug resistance of Mycobacterium tuberculosis in selected urban and rural areas in Bangladesh. Scand J Infect Dis 2005; 37:21-6. [CrossRef]

11. Espinal MA, Laserson K, Camacho M, Fusheng Z, Kim SJ, Tlali RE, et al. Determinants of drug-resistant tuberculosis: analysis of 11 countries. Int J Tuberc Lung Dis 2001; 5:887-93.

12. Caminero JA, Sotgiu G, Zumla A, Migliori GB. Best drug treatment for multidrug-resistant and extensively drugresistant tuberculosis. Lancet Infect Dis 2010; 10:621-9. [CrossRef]

13. Nitta AT, Milligan D. Management of four pregnant women with multi-drug resistant tuberculosis. Clin Infect Dis 1999; 28: 1298-304.

14. Drobac PC, del Castillo H, Sweetland A, Anca G, Joseph JK, Furin J, et al. Treatment of multidrug resistant tuberculosis during pregnancy: long-term follow-up of 6 children with intrauterine exposure to second-line agents. Clin Infect Dis 2005; 40:1689-92. [CrossRef]

15. Lessnau KD, Qarah S. Multi-drug resistant tuberculosis in pregnancy: case report and review of the literature. Chest 2003; 123:953-6.

16. Shin S, Guerra D, Rich M, Seung KJ, Mukherjee J, Joseph K, et al. Treatment of multidrug-resistant tuberculosis during pregnancy: a report of 7 cases. Clin Infect Dis 2003; 36:996-1003. [CrossRef]

17. World Health Organization (WHO). Guidelines for the programmatic management of drug-resistant tuberculosis. Access date: 25 November 2010. Place of access

18. Craig GM, Booth H, Story A, Hayward A, Hall J, Goodburn $A$, et al. The impact of social factors on tuberculosis management. J Adv Nurs 2007; 58:418-24. [CrossRef]

19. Starke JR. Tuberculosis. An old disease but a new threat to the mother, fetus, and neonate. Clin Perinatol 1997; 24:107-27.

20. Palacios E, Dallman R, Muñoz M, Hurtado R, Chalco K, Guerra D, et al. Drug-resistant tuberculosis and pregnancy: treatment outcomes of 38 cases in Lima, Peru. Clin Infect Dis 2009; 48:1413-9. [CrossRef] 